\title{
MEDIA AND TECHNOLOGY: DIGITAL OPTIMISTS AND DIGITAL PESSIMISTS
}

\author{
UDC 316.774:004.738.5
}

\author{
Anka Mihajlov Prokopović \\ University of Niš, Faculty of Philosophy, \\ Deparment of Communicology and Journalism, Niš, Serbia
}

\begin{abstract}
This work examines the relationship between mass media and digital technology by following McChesney's argument (2013) that the division on the technological optimists and technological pessimists is gaining in significance again. The debate between these two currents, which has been ongoing since the beginning of the Internet with variable intensity, has enabled many advantages and many disadvantages brought by the digital age is discussed in its "pure form". The work is conceptualization of the following themes: the nature of the mass media, the characteristics of digital life, citizens' participation in the creation of content on digital platforms and the future of journalism, as they are seen by these two theoretical approaches.
\end{abstract}

Key words: media, internet, technology, technological optimists, technological pessimists.

\section{INTRODUCTION}

Although it seemed that the technological optimists and pessimists remain a part of media archeology, the debate is now again being ignited, of course, about a new issue. One of them is the increasing citizens' participation in creating media content. The question that arises is whether it is a contribution to democratization and media pluralism. Henry Jenkins, whom many refer to as the new McLuhan, considers that collective intelligence is happening (a term taken from the French theorist Pierre Levy): "None of us can know everything; each of us knows something; and we can put the pieces together if we pool our resources and combine our skills. Collective intelligence can be seen as an alternative source of media power. We are learning how to use that power through our day-to-day interactions within convergence culture" (Jenkins 2006, 4). The exact opposite of Jenkins' stand is that of Andrew Keen, who points out that although our mouths are full of democratization that brings the Internet into the field of big business or big media industry, it is actually about the transformation of experts into amateurs, admittedly "noble amateurs". "The new internet

Received June 6, 2017 / Accepted June 16, 2017

Corresponding author: Anka Mihajlov Prokopovic

University of Niš, Faculty of Philosophy, Cirila i Metodija 2, 18000 Nišs, Serbia

E-mail: anka.mihajlov.prokopovic@filfak.ni.ac.rs 
was about self-made music, not Bob Dylan or the Brandenburg Concertos. Audience and author had become one, and we were transforming culture into cacophony" (Keen 2007, 14). The mass media in their attempt to inform the public fairly and objectively is being changed by hundreds of bloggers who create a multitude of redundant information because everybody is talking mainly about themselves. It is further, said Keen, leading to devaluation of work and the impact of critics, journalists, publishers, directors and other experts who are easily replaced by the "influential bloggers". "We - those of us who want to know more about the world, those of us who are the consumers of mainstream culture - are being seduced by the empty promise of the 'democratized' media. For the real consequence of the Web 2.0 revolution is less culture, less reliable news and a chaos of useless information. One chilling reality in this brave new digital epoch is the blurring, obfuscation, and even disappearance of truth" (Keen 2007, 16). As you can see there is still a clear line between technological optimists and pessimists, and this article will show the development of these two approaches and outcomes of the debate.

\section{TECHNOLOGICAL OPTIMISM}

Today, most scholars agree that Marshall McLuhan predicted the emergence of a globalized world (Radojkovic and Miletic 2005, 24). Technological development has led to the fact that all people are connected in one community, a global village, said McLuhan in the sixties. "Our present acceleration is not a light explosion directed from the center towards the margins, but the current implosion and mutual blending of space and functions. All mechanized bits of our specialist and fragmented civilization of central-marginal structures are unexpectedly subjected to current reassembly into one organic whole. This is that new world of global village" (McLuhan 1971, 134-135). McLuhan's technological determinism is clearly manifested in his famous formulation "the medium is the message" by which he gives absolute priority to the effect of the media as technology. McLuhan believes that one social whole is basically formed by the general, and, primarily by its very nature, and that the issues of message content are completely irrelevant. "Our conventional response to all information - namely, that it is important how it is used reflects the insensitive attitude of the technological idiot. Because the content of a medium is as a juicy piece of meat carried by the burglar to distract the watchdog of the mind" (McLuhan 1971, 53).

Taken from McLuhan, this interpretation of the relationship between media and technology that insists on the benefits that technology brings is represented by Nicholas Negroponte in the book "Being Digital" (1998), a digital manifestation of the digital age, Antoine Iris in "Information Highway" (1999) and many others up to present actual Henry Jenkins (2006), Clay Shirky (2010) and Jeff Jarvis (2011).

Negroponte is the representative of the dominant group of internet supporters. Although at one point it seemed that this division has been overcome, McChesney, the next Robin Mansell (2012), brings it back to life in his book "Digital Disconnect: How Capitalism is turning the Internet against Democracy" in which he gives an overview of authors of the second wave of internet supporters and skeptics (McChesney 2013, 4-16).

Nicholas Negroponte, founder of the Media Laboratory at the famous MIT university, talks about the triumph of the digital age, which has four powerful qualities - decentralization, globalization, harmonization and strengthening (Negroponte 1998, 215). Decentralization is the consequence of development first in the computer industry, then it becomes one of the 
principles of functioning of the digital society (Negroponte often uses the term being digital). Within globalization Negroponte includes the consequences which lead to the disappearance of the state, comparing it to mothballs, which evaporate in a way that solids transform into a gaseous state. Connecting people is no longer conditioned by geography, it is possible to establish cooperation among people in different parts of the world, what would make that world more harmonious, as Negroponte believes. Negroponte draws his optimism from "the invigorating nature of the digital lifestyle. Access, mobility and ability to affect the change are factors that will make the future so different from the present" (Negroponte 1998, 217). Although, as pointed out by the author, new discoveries will arise thanks to digital technology, the essence of being digital lies not only in its discoveries but in the fact that "each generation will be 'more digital' than the previous one" (Negroponte 1998, 217-218).

In a world that has gone digital, the medium is not the message, but its embodiment, as Negroponte claims, referring to McLuhan's influential thesis of the nineteen sixties and seventies. One message, thanks to digital technology can be presented in many different ways. The same bits (atomic elements of information as it explains Negroponte) can be embodied as text, sound, images or video (Negroponte 1998, 72-73).

\section{TEChNOLOGICAL PESSIMISM}

At the other pole are the authors who are skeptical about the achievements of technology. In that spirit French philosopher Jean Baudrillard formulated his theory, claiming that the production of goods in the modern world whose main characteristic is hyperreality, is not its function, but the constant production of simulacrum. The simulacrum is "something real without origin and reality: something supernatural" (Baudrillard 1991, 5). The example of simulation given by Baudrillard is a healthy person who simulates the symptoms of a disease; therefore, he is neither healthy nor sick; medicine loses its meaning since it only knows how to treat "real" illnesses according to their objective causes. The loss of meaning is the result of simulation (Baudrillard 1991, 5-35).

Although media produce more and more information, they are becoming less meaningful. Whatever they have been doing, it is merely the constant production of simulacra, empty images behind which there is nothing. What is the implosion of meaning? Baudrillard explains it like this: "There are no longer media in the literal sense of the term (I'm talking above all about the electronic mass media) - that is, there is no longer an instance of an intermediary between one state of the real and another, neither in content nor in form. Strictly speaking this is what implosion signifies" (Baudrillard 1991, 87). The media deal with fake communication or fake sense, leading to an ultimate dissolving of the "real" and "the total entropy" (Baudrillard 1991, 84-85). Charlie Gere in his retrospective of theorists who influenced digital culture described Baudrillard as the embodiment of the postmodern hopelessness (Gere 2011, 153).

At the very end of the pessimistic spectrum theories about the nature of the new information technologies and their effects on society is the apocalyptic vision of the French philosopher Paul Virilio (2000). The growth of the information and all the more modern means of its use at the global level, Virilio is warning, will lead to the rule of virtual disinformation (Virilio 2000, 107). Even though the internet has its good sides, the outcome of the development of this technology will be tragic: "Progress consists in communicating almost without limits, but the trouble is that the Titanic of virtual sailing will one day come 
across an iceberg. As a result of 'techno-sophist' illusion, from the end of the Cold War, or the 'end of history', cybernetics of the network over networks is not that much a technology but a system - techno-system of strategic communication - which carries a systemic risk, the risk of a chain reaction of failures, which will happen as soon as mondialisation is achieved" (Virilio $2000,106)$. This chain reaction will lead to the creation of an information bomb that poses a threat to the whole world because it is based on information interactivity (Virilio 2000, 65). Dangers, as said by Virilio, appear in almost all areas in which the Internet becomes indispensable - from the economy, which is undermined by the guerrilla business, everyday life in which technology and the internet are used for continuous monitoring (such as, for example, increasing the number of security cameras keeping public spaces under surveillance in developed countries and increased transfer of live images on the Internet) that Virilio called optical snitching (Virilio 2000, 65-67). Online cameras, emphasizes this theorist, in addition to achieving expediency for the sake of obvious goals such as trade or tourism, have become the means of mass self-observation. In these circumstances television can no longer play the same role as before (when producing entertainment and cultural program), it must now create "a virtual vision that expresses the vision of the real world around us" (Virilio 2000, 20). So "first reality should be abolished today, at all costs, by creating a stereo reality composed, on the one hand, from the actual reality of actual appearance and, on the other hand, from virtual reality of media trans-appearance" (Virilio 2000, 20). Computer technology is gaining the characteristics of an information bomb since the purpose of its use equals war goals. In the past, this was literally the case, because this technology was used to develop nuclear weapons, and today computer technology is used to decipher the human genetic code, says Virilio indicating experiments in this field (Virilio 2000, 133-138).

It has already been mentioned that McChesney revived the division into optimists and pessimists so that in the second decade of the twentieth century, although in smaller number than optimists, technology pessimists are heard, including McChesney, Jaron Lanier (2010), Evgeny Morozov (2011), Sherry Turkle (2012) and Nicholas Carr (2010) (McChesney 2013, 8-12).

\section{THE OUTCOMES OF THE DEBATE TECHNOLOGICAL OPTIMISM-TECHNOLOGICAL PESSIMISM}

The focus of Internet applications on a small group of the dedicated was characteristic for the beginning of the nineties when researching the Internet was in the hands of computer experts and inventors. According to the testimony of professor of sociology Dr. Barry Wellman, who was among the first scientists in the field of social sciences involved in the study of the Internet, it was not likely to most members of the research group that the internet would ever been involved in daily life and work and stop being only an academic chat room. The presentation of professor Wellman at the conference dedicated to computer research $(\mathrm{CSCW})$ in 1992, when he expressed his opinion that the future of the Internet lay in its expansion and usage by citizens, although politely listened to, then did not have a significant impact. As we know, somewhat later, things have changed completely.

In that first phase, when the Internet became a powerful tool of communication and left the academic rooms, which began in 1994 and lasted until 1998 (Wellman 2004, 124), the euphoria dominated in the approach to the opportunities provided by the Internet. The Internet was praised as a technological miracle that has overcome the spatial and temporal 
boundaries. The text of John Barlow published in 1995 is characteristic of this approach in which he says that the Internet has been the greatest discovery since the days when people discovered fire (Barlow 1995, 36 referred in Wellman 2004, 124). Theorists who have in this way approached the Internet often spoke in assumptions. There were no data on the Internet, so the texts were reduced to "anecdotal evidence: the stories of passengers from the unknown lands of the Internet" (Wellman 2004, 124). These analyses were often utopian and praised the internet as a technology that contributes to democratization throughout the world, while ignoring the relations of power on a global stage and the economic situation of developing countries. On the other hand, supporters of dystopian perspective indicated the shortcomings the internet has, which at this stage were primarily identified as "dependence on a screen" and virtual communication that could replace human communication face to face. Sociological perspectives to the study of the Internet have been provided by Wellman in his two texts, which, as he himself stated, are a kind of manifesto. In the first "An electronic group is virtually a social network" (1997) he submits that the Internet is a social network based on computer technology. Two years later he published another article entitled "Netsurfers do not ride alone" (1999) claiming that although the Internet is a new technology, it is not an entirely new world. In fact, the dynamic that is part of the community and relationships in the offline world are intertwined with the relationships in the online world.

From this first stage, the Internet studies enter into the second phase (1998-2003), characterized by "calming of the soil" and a systematic approach reflected in a new approach of government, theorists and industry, which has resulted in the creation of a documentation basis. The Internet is becoming part of daily life. "We have passed from the world of the Internet wizards in the world of ordinary people who routinely use the Internet. The Internet has become an important thing, but not a special thing. It has become primarily useful for all and not just a toy for computer scientists" (Wellman 2004, 125). The democratization of the Internet is happening, which brings everyone the possibility of using the internet by using simple applications. This process is followed by research and initiating long-term projects that deal with the study of the Internet. Wellman quotes two such projects: Pew Internet \& American Life Project (http://www.pewinternet.org) and the World Internet Project (http://www.worldinternetproject.net). It has become apparent that the predictions of neither optimists nor pessimist came through when it comes to the internet. So, at this stage, the debate between the optimists and the pessimists has been abandoned, and passed on what might be called the collection of data on the Internet and the interpretation of these data.

From this "documentary" phase, the studies of the Internet soon entered, a few years later (2003), into a new phase, the phase of analysis, which opened a wide field where new theoretical concepts were required, not just "eloquent euphoria" typical for the first stage or "the standard methods of the social sciences and some concepts of documenting the nature of the internet" that marked the second stage (Wellman 2004, 127). The author of this periodization Wellman, stated that his approach to the Internet has evolved from interaction within a group to the understanding of the Internet as individualized networks. These individualized networks are enabled thanks to personalization, access to the Internet, omnipresent connectivity and wireless internet, therefore, thanks to technological progress, and represent information and communication distributors among individuals, networks and institutions.

Studies of media and journalism in their early attempts to capture changes that have brought the internet to the world of traditional media examined the technological capabilities 
and their ability to change and improve journalism (Deuze 2001, Pavlik 2001, Boczkowski 2004, Domingo 2006, Paulussen 2004, Jankowski \& Van Selm 2000, Dahlgren 2006). Although even among them we can see the division into those who claim big expectations when it comes to the benefits of the Internet and those who are pessimistic, the research focus is concentrated here on the impact of the Internet on traditional media. In these analyses the studies examining the technological advantages of the Internet for online media and online journalism were dominant. The most common researched benefits are hypertextuality, multimedia and interactivity (Deuze 2001, Domingo 2006, Paulussen 2004, Jankowski \& Van Selm 2000, Steensen 2011). These features of the Internet for many theorists represented a significant opportunity for a major change in journalism and the achievement of full communication capabilities, and therefore David Domingo called them "utopia of online journalism" (Domingo 2006, 54).

Technology-based studies have led to the domination of research of the impact which Internet characteristics have on traditional media in the first decade of the development of online journalism. This period Domingo divided into three phases. The first is dominated by normative studies, the second dominated research into the implementation of new technologies in journalism, and the third phase Domingo called constructivist, wishing to point out that empirical studies rely on a constructivist approach to understanding technological changes (Domingo 2006, 137). In the second decade, a new phenomenon became the focus of scientific attention, so the attention was attracted by blogs, social networks as platforms for media promotion, new genres like live blog, etc. The field is thematically diversified, as observed by Mitchelstein \& Boczkowski (2009).

A large number of studies still have a technological approach, but the results show that the media did not take advantage of this new technology. In a review of the literature dealing with technological innovation in online journalism Steen Steensen (2011) shows that traditional media in their publications are use text much more than hypertext and multimedia possibilities. Also, the role of media in deciding what constitutes news agenda remains untouched, while the content made by citizens is integrated into that agenda. Interactivity is gaining significance only when monitoring the striking events in crisis areas is on the agenda. Editors and journalists have shown a willingness to accept the changes that the digital world brings, while users of it are not very interested (Steensen 2011, 10).

Steensen noticed a breakthrough of ethnographic research into the field of online media, believing that they offer a new chance for the interpretation of the direction in which online journalism is developing. Thus, he points out, as a result of his research, the degree of innovation of the online newsroom is influenced by many factors including: the autonomy of the editorial board, editorial work culture, the role of management, the importance of new technologies and innovative individuals (Steensen 2009).

Considering that many concepts are intertwined in this area, it requires a theoretical discussion and a clearer definition of key terms. Steensen gives the example of vagueness and overlapping of meanings when it comes to interactivity, hypertextuality and multimedia (Steensen 2011, 11). There is no longitudinal component in the research of media in the digital sphere, which may be the result of a lack of a common theoretical and methodological basis (Steensen 2011, 11).

One of the issues that preoccupied the attention of media theorists is the pursuit of the economic model of digital media. John Pavlik in his analysis proposes four models: advertising, e-commerce, subscription and partnership (Pavlik 2008, 153). Although most traditional media in their online editions offer their content for free, Pavlik mentions the 
example of large newspapers such as The New York Times, which have introduced payment for selected articles and archives (Pavlik 2008, 164). However, it is difficult to predict a successful business model in the digital environment because frequent changes in technology require a high degree of adaptation of media organizations as well as users, says the author. He points out that for quality media content in the digital sphere a subscription should be paid and that it is a risk for democratic communication. Even in developed societies such as the American one, the poor strata of society remain unable to access the content, and the situation is now becoming worse than before, because then there was relatively inexpensive local newspapers and free television and radio news programs. Another obstacle to be overcome by marginalized groups of society is the adoption of computer skills, which also makes it difficult to participate in the democratic process (Pavlik 2008, 167-168).

Changes that alter American journalism brought by the digital world are the topics of Leonard Downie, Jr. and Michael Schudson's text "The Reconstruction of American Journalism" (2009). In this paper, the authors provide an overview of the status of the American press pointing to a major crisis that hit the sector in 2008, which is shown through the reduction of income and as a consequence further manifested through dismissal of employees, reduction of costs, reduction of rhythm of publishing and reducing of pages dedicated to informative journalism. More than a hundred newspapers have given up Saturday's release or release of another working day, and the daily newspapers in Denver, Seattle and Tucson ceased to exist. Many newspapers have decreased their number of journalists dramatically. For example, the editorial staff of The Baltimore Sun was reduced in 2009 to only 150 journalists from more than 400 who had been employed Los Angeles Times was forced to dismiss 500 journalists out of the 1100 employed until then. The number of employees in the whole print media industry in this period was reduced from 60 thousand, in 1992, to 40 thousand. Many areas that were previously reported on and which were of public interest, such as reporting on government activities and economic issues, have become poorly "covered" or are totally left out from newspapers. Many newspapers reduced the number of journalists in investigative journalism, while the large printed media fired foreign correspondents and reduced the number of correspondents from Washington. The number of full-time reporters from Washington DC declined from 524 in 2003 to 355 reporters in early 2009 (Downie \& Schudson 2009, 5).

Although many newspapers have tried to reduce expenses and make profit from online advertising on their websites (which all of them have) this model does not allow it still, and it remains unknown whether it will be ever capable to allow sustainable journalism in the public interest. In any case, the days when the big printed media earned enough to provide accountability journalism have passed. Various experimental economic models are being developed which the authors Downey and Schudson identified in practice by exploring the media all over America. Among them, there are regionally affiliated newspapers which are working together (united newsrooms) on most topics, although there are areas that they keep exclusively only for their own journals. There are digital platforms where the news is made together by professionals and non-paid amateurs. When it comes to local information other variants are being developed for which the costs are low, such as the establishment of local news agencies where young, lower-paid journalists are working (Downie \& Schudson $2009,6)$. At the time when the authors were doing this research, the role of and listening to network radio stations that made the National Public Radio was gaining strength in America which wanted "to fill the gap left by shutting down the local newspaper" and offer more local news program (Downie \& Schudson 2009, 8). Professional journalists who have lost 
their jobs were consolidated in order to continue to report in the public interest and form online media in which they often work for free (Downie \& Schudson 2009, 12).

Because of the print crisis, as well as the growing number of new actors who provide information in the digital world, the press will play a much smaller role than it did before the appearance of digital journalism. And that, in the opinion of these authors, will not be good for responsible journalism, especially when it comes to reporting from local communities. Why? The largest part of the information and analysis, when the responsible journalism in America is in question, was provided by the press (Downie \& Schudson 2009, 1). The number of journalists who worked in the editorial news boards on television and radio stations were small even at the time when revenues were high, and during the crisis it experienced a reduction (Downie \& Schudson 2009, 7). Still most of the content of journalism in the public interest that appears on the internet is taken from daily newspapers or from their online editions (Downie \& Schudson 2009, 4). In order to start and maintain a website dedicated to analytical journalism it is necessary to engage professional journalists, but online media revenues are too low to finance a big editorial office. Although it is valuable for many of them to rely on citizens, journalism students, members of non-governmental organizations with whom they jointly check data and with whom they have opposing opinions, it is not enough for a professional approach to issues as it was developed in the press. This journalism has become known as collaborative journalism, and Alan Rusbridger, the editor of Guardian, called it "mutualised newspaper" (Downie \& Schudson 2009, 2). Many initial attempts at establishing and developing websites that would provide local news suggest restrictions which a small number of employees, small audience and small budgets are carrying (Downie \& Schudson 2009, 11).

But in order to obtain reporting in the public interest that is no longer as profitable as it was during the blooming of press at the end of XX century, when advertising revenues could finance large newsrooms as well as diverse and high-quality reporting, the authors suggest that the state should help such online coverage by financing it from its funds and free it from taxes. The authors elaborate and justify it (Downie \& Schudson 2009, 15-22) by the interest of citizens to be informed about the key issues of public importance in an objective manner, reminding us that such funding should also be provided for other matters of public interest such as science, art, health. In this way the influence of the state could also be controlled in terms of finance.

\section{CONCLUSION}

This work shows that the authors who celebrate the new era of the Internet point out its advantages when it comes to journalism. This is about removing barriers for doing proper journalism embodied in the motto "we are all journalists now", the great possibilities for using information just by searching the Internet, that journalists are able to create their own texts in cooperation with interested individuals online and how the internet is significantly reducing the costs of production and distribution so that with a small investment a big readership can be achieved, or a large audience acquired (McChesney 2013, 174).

Robert McChesney claims that the Internet is not the cause of the big crisis that journalism is experiencing. He believes that the cause is commercialization, i.e. media ownership and support of advertisers (McChesney 2013, 175). These two factors, through the affirmation of the commercial values before the Internet jeopardized the control - watchdog role of 
journalism, undermined professional standards, enabled trivialization of content and reduced journalism to post festum response when events escalate - hindsight-journalism. Journalism is a public good, and considering that the market is no longer able to provide "sufficient quantity and quality" journalism, it is necessary to find new solutions (McChesney 2013, 175).

McChesney mentions several times the internet optimists' attitudes, i.e. those authors who celebrate the Internet and its possibilities. Without denying the potential for democratization that is immanent to the internet, McChesney points out the fact that the capital has taken the internet and halted its democratic possibilities. There are two aspects in which this is clearly visible. The first aspect reveals a high concentration in the digital world. In order for a company earn money in online journalism it must be big, centralized and have an almost monopolistic position. Concentration is strengthened by the principle which is embedded in the browsers on the Internet which are increasing visits to the already most visited sites (using a rating system). McChesney illustrates it like this: "Ten most visited US Web sites attracted 31 percent of visits in 2001, 40 percent in 2006 and about 75 percent of visits in 2010" (McChesney2013, 190). The four most visited sites in 2012 were Google, Microsoft, Yahoo and Facebook, and these very same companies have attracted two-thirds of the revenue from advertising on the Internet (McChesney2013, 190). And while the big are getting bigger, poorly visited sites remain small, and medium-sized sites do not exist. The concentration in the digital world is higher than in the world of traditional media (McChesney 2013, 190-191). Another aspect lies in the fact that journalists are doing more while their salaries are getting smaller. Some economic models of online media are based on the unpaid work of amateurs as well as the little paid freelancers. This model is known as the journatic business model (McChesney 2013, 192). The Internet has increased the tension between commercialization and journalism, and as a result generated light and entertaining content - soft news.

The Internet did not democratize capitalism and made it new, says McChesney. In favor of this he says that among the 30 richest American companies there are 13 internet giants, but among the 30 companies that have the largest number of employees, only four are in the world of internet business. That is a lot of money for those on top, and little for others (McChesney 2013, 223). Accordingly, McChesney writes: “... internet giants are not a progressive forces. Their big profits are the result of monopoly privileges, network effects, commercialization, exploited labour and a number of government policies and subsidies" (McChesney 2013, 223).

McChesney, as well as Downey and Schudson, emphasizes the importance of social factors in determining the manner in which to use the Internet. The development of the Internet, McChesney notes, "is complexly connected" with the development of political economy (McChesney 2013, xiii). Society chooses the way to develop the technology, and reciprocity is reflected in the way this choice is affecting society (McChesney 2013, 216). These authors are promoting a greater impact of society through public policies in order to develop the use of the Internet for the benefit of the community. "American Society must take collective responsibility for supporting independent news reporting in this new environment"' (Downie \& Schudson 2009, 14).

How journalism should survive in the digital field as a public good is a question that McChesney tries to answer. The media dealing with responsible journalism is no longer economically sustainable because advertising revenues are small. Even the English Guardian, which has vast resources and whose online edition has great visits and popularity, cannot successfully move to the digital sphere and maintain quality (McChesney 2013, 201). The 
model of financing media through advertising that had been operating for 125 years is no longer functional. The funds from local advertising which previously went to the local press have moved to the Internet, but not to the media sites that deal with informative journalism (McChesney, 2013, 186).

Public investments in journalism are necessary in this period when the media market has collapsed (McChesney2013, 211). The proposal given by McChesney is very specific - that citizens should finance nonprofit news media of their own choice via vouchers that should be distributed to every adult citizen of America (McChesney 2013, 211). What kind of media could be funded in this way? Those media who meet the requirements of producing original content and media that is not a part of a larger organization which performs another non-media related business. The obligation of these media would be that the entire media content be immediately published on the Internet and that it is available to everyone for free. In addition, these media could not make any income from advertising, but could accept donations. Given that this internet media sector would function without revenue from advertising, the money of the advertisers would go to the commercial media, which could count on the development of a sustainable economic model. On the other hand, non-profit media could use this voucher income from the audience to be sustainable and to ensure full payment for their employees (McChesney 2013, 212). McChesney $(2013,215)$ ends with a warning: If the Internet is really reviving American democracy, it is taking a roundabout route, while in the sphere of journalism, its failures are already visible.

\section{REFERENCES}

Boczkowski, Pablo. Digitizing the News: Innovation in Online Newspapers. Massachusetts: The MIT Press, 2004. Bodrijar, Žan. Simulakrumi i simulacija. Novi Sad: Svetovi, 1991.

Carr, Nicholas. The Shallows: What the Internet is Doing to Our Brains. New York: W.W. Norton, 2010.

Dahlgren, Peter. "Civic Participation and Practices: Beyond 'Deliberative Democracy." In Researching Media, Democracy and Participation, edited by Nico Carpentier et al., 23-35. Tartu: Tartu University Press, 2006. Available at: http://yecrea.eu/files/teaching_series_1ok.pdf.

Deuze, Mark. "Online Journalism: Modeling the first generation of news media on the World Wide Web". First Monday 3.341 (2001). http://www.firstmonday.org/issue6_10/deuze/index.html

Domingo, David. "Inventing online journalism. Development of Internet as news medium in four Catalan online newsroom" (PhD dissertacion). Universitat Autonoma de Barcelona, 2006. Available at: http://www.tdx.cat/ bitstream/handle/10803/4190/dd1de1.pdf?sequence=1

Downie, Leonard Jr., and Michael Schudson. "The Reconstruction of American Journalism". Columbia Journalism Review (2009) Available at: http://www.cjr.org/reconstruction/the_reconstruction_of_american.php

Gir, Čarli. Digitalna kultura. Beograd: Clio, 2011.

Iris, Antoan. Informacione magistrale. Beograd: Clio, 1999

Jankowski, Nicholas W., and Martine Van Selm. "Traditional News Media Online: An Examination of Added Values." Communications 25, 1 (2000): 85-101.

Jarvis, Jeff. Public Parts: How Sharing in the Digital Age Improves the Way We Work and Live. New York: Simon \& Schuster, 2011.

Jenkins, Henry. Convergence Culture: Where Old and New Media Collide. New York and London: New York University Press, 2006.

Keen, Andrew. The Cult of Amateur. New York: Doubleday, 2007.

Lanier, Jaron. You Are Not a Gadget: A Manifesto. New York: Knopf, 2010.

Makluan, Maršal. Poznavanje opštila: čovekovih produžetaka. Beograd: Prosveta, 1971.

McChesney, Robert W. Digital Disconnect: How Capitalism is Turning the Internet against Democracy. New York: The New Press, 2013.

Mitchelstein, Eugenia and Pablo Boczkowski. "Between Tradition and Change: A Review of Recent Research on Online News Production.” Journalism 10, 5 (2009): 562-586.

Morozov, Evgeny. The Net Delusion: The Dark Side of Internet Freedom. New York: Public Affairs, 2011. 
Negropont, Nikolas. Biti digitalan. Beograd: Clio, 1998.

Paulussen, Steve. "Online News Production in Flanders: How Flemish Online Journalists Perceive and Explore the Internet's Potential.” Journal of Computer-mediated Communication 9, 4 (2004): 00 (no pagination). Available at: http://onlinelibrary.wiley.com/doi/10.1111/j.1083-6101.2004.tb00300.x/full

Pavlik, John. Journalism and New Media. New York: Columbia University Press, 2001.

Pavlik, John.Media in the Digital Age. New York: Columbia University Press, 2008

Radojković, Miroljub i Mirko Miletić Komuniciranje, mediji i društvo. Novi Sad: Stylos, 2005.

Shirkey, Clay. Cognitive Surplus: Creativity and Generosity in a Connected Age. New York: Penguin, 2010.

Steensen, Steen. "What's Stopping them? Towards a Grounded Theory of Innovation in Online Newspapers." Journalism Studies 10, 6 (2009): 821-836.

Steensen, Steen. "Online Journalism and the Promises of New Technology: A Critical Review and Look Ahead." Journalism Studies 12, 3 (2011): 311-327.

Terkl, Šeri. Sami zajedno: zašto očekujemo više od tehnologije nego jedni od drugih. Beograd: Clio, 2011

Virilio, Pol. Informatička bomba. Novi Sad: Svetovi, 2000.

Wellman, Barry. "The Three Ages of Internet Studies: Ten, Five and Zero Years Ago." New media and Society 6, 1 (2004): 123-129.

\section{MEDIJI I TEHNOLOGIJA: DIGITALNI OPTIMISTI I DIGITALNI PESIMISTI}

$U$ ovom radu razmatra se odnos masovnih medija i digitalne tehnologije pri čemu se sledi argument Mekčesnija (McChesney 2013) da podela na tehnološke optimiste i tehnološke pesimiste ponovo postaje aktuelna. Debata između ove dve struje traje od nastanka interneta, sa promenljivim intenzitetom $i$ omogućila je da mnoge prednosti i mnoge mane koje donosi digitalno bivanje budu razmotrene $u$,čistom vidu". Rad predstavlja konceptualizaciju tema: priroda masovnih medija, karakteristike digitalnog života, učešće građana u kreiranju sadržaja na digitalnim platformama i budućnost novinarstva, onako kako ih vide ova dva teorijska pristupa.

Ključne reči: mediji, internet, tehnologija, tehnološki optimisti, tehnološki pesimisti. 